\title{
Saraje pashallarësh në Elbasan, por kush ishte pashai?
}

\author{
Riza Hasa
}

Gjatë punimeve për restaurimin e rrugës "Thoma Kalefi" në qytetin e Elbasanit, në vitin 2013, u zbulua një segment muri, i cili shkonte paralel me rrugën në pjesën perëndimore të saj me orientim veri-jug. Segmenti i zbuluar ka një gjatësi rreth $70 \mathrm{~m}$ dhe një trashësi rreth $1 \mathrm{~m}$. Teknikisht është treguar punë e kujdesshme për ndërtimin e tij. Janë përdorur gurë lumi të punuar dhe lidhur me llaç të fortë. Nga gërmimet, vetëm nga pjesa veriore $u$ arrit të shihej struktura e objektit deri në fundin e tij (në pjesën jugore nuk vazhduan gërmimet). Në këndin që krijojnë linjat e murit, zbulohet pjesërisht një kullë fortifikimi, në të cilën ruhen mirë frëngjitë për përdorimin e armëve të vogla të zjarrit. Kjo e dhënë e shfaqur dukshëm, u jep mundësinë specialistëve të orientohen për datimin e këtij objekti, por siç ndodh në kësi rastesh, të parët që flasin dhe hamendësojnë janë “kompetentët amatorë’. Kështu u tha se kemi të bëjmë me një rezidencë feudale paraturke dhe e lidhnin me principatat feudale të shekullit të XIV ose prej disave iu vu dhe emri "Kala e jeniçerëve".

Mendimi që gjeti më shumë përkrahës, i cili është publikuar edhe në shumë shkrime, ${ }^{1}$ ka qenë ai se "kemi të bëjmë me Jenixhe kalanë" që përmendet nga kronikat, të cilat këtë d.m.th. "Jenixhe kalanë" ose "Kalanë e re", e vendosin në Bradashesh, më saktë në fshatin Fikas, sepse këtu ekspozoheshin fragmente muresh të një ngrehine antike të cilën banorët e quanin kala e Bradasheshit. ${ }^{2}$ Kjo e dhënë pati tërhequr me kohë vëmendjen e studiuesve, prandaj në vitet 1968-69, u kryen gërmime sistematike arkeologjike, të cilat dëshmuan, që në të dhënat e para se "nuk kishim të bënim me një ndërtim mbrojtës siç pritej

1 Kryesisht janë shkrime gazetareske.

2 Shyqyri Demiri, Histori e shkurtër e trevave të Elbasanit, Egnatia 2006, f. 161. 


\section{Albanon}

Revistë kulturore

nga emri, pra me një kala, por me një nymfe $e^{1}$ dhe terme antike të ndërtuar në funksion të rrugës Egnatia"." Me një fjalë "Jenixhe kalanë" nuk duhet ta kërkonim këtu.

Po ku? Përgjigjen për "Jenixhe kalanë", na e jep emri që u thirr nga popullsia vendase dhe prej botës së jashtme joturke qyteti ynë, Elbasani, në shekujt e parë pas pushtimit osman.

Sipas profesor Hasan Cekës, në dy shekujt e parë pas ndërtimit të tij “... qyteti është thirrur me emrin, Qytet i Ri, Terranuova, Civitanuova dhe Neokastron ${ }^{3}$." Emri i dikurshëm, ashtu si i shumë qyteteve të tjera antike, u zhduk nga kujtesa dhe i mbeti vetëm lumit Shkumbin.

Në vitin 1466, turqit, siç na thotë mbishkrimi i vendosur mbi portën jugore të kalasë, e quajtën kështjellën që rindërtuan Jilbasan ${ }^{4}$. Emri Jilbasan na përmendet në burimet historike për herë të parë në vitin 1519. ${ }^{5}$ Ky emër, siç u tha më lart nuk gjeti vend ose si të thuash nuk "ngjiti” te vendasit, pra nuk është pranuar, jo vetëm nga kuptimi që kishte, por mendojmë, edhe sepse popullsia akoma nuk ishte islamizuar masivisht d.m.th. i rezistuan këtij emri të vënë nga pushtuesit dhe ky emër “do të zinte vend” më vonë, kur bashkë me "pranimin e fesë islame", u pranua dhe emri i ri aty rreth shekullit tëXVII.

Njëkohësisht me këtë emër, si të thuash zyrtar turk, qyteti, në këto shekuj të parë pas pushtimit është thirrur edhe "Neokastër". Edhe këtë emër e gjejmë

1 Neritan Ceka, Lazër Papajani. Nymfeu dhe termet e stacionit, Ad Quintum. Monumentet, 4, 1972.

2 "Nymfeu dhe termet përbënin një kompleks të vetëm arkitektonik dhe krijonin një stacion që duhet t'u shërbente udhëtarëve që kalonin në rrugën Egnatia. (Nymfet janë godina në të cilat shfrytëzohen burime uji të rrjedhshëm. E kanë marrë këtë emër se mendohej që në këto burime banonin nymfat, hyjnitë e ujërave, kurse termet janë banjo publike në të cilat udhëtarët bënin banjon e trupit. Kështu këto gërmime zbuluan stacionin e rrugës Egnatia të cilin e përmendnin itineraret e rrugëve antike me emrin "Ad Quintum", d.m.th. deri 5milje nga Skampini. Sot është ai një aset i veçantë dhe i rëndësishëm arkeologjik, është edhe i vizitueshëm.

3 Hasan Ceka, Në kërkim të historisë ilire, Tiranë 1988, f. 256.

4 Hasan Ceka, Po aty, f. 257.

5 Simbas prof. Shyqyri Demirit, fjala ljl ose il ose li do të thotë vend, krahinë dhe basan do të thotë shtypës d.m.th. vend -shtypës, në kuptimin më të gjerë kala zotëronjëse, kurse orientalisti i shquar Franc Babinger në studimin e tij për themelimin e Elbasanit, për kuptimin e emrit Ilbasan ose Elbasan ka gjetur fjalën gjermane "Besetzung" që ka kuptimin "zënie", "pushtim". Në dokumentet historike perendimore, emri i qytetit të ri "Elbasan" do të përmendet, siç u tha, për herë të parë në historinë e Marchese Guilelmo, shkruar në vitin1519 prej sekretarit të tij, Benvenuto Sante Xhorxhio. Aty flitet për Kostantino Arianites. "Ai (Kostantino Arianites) zotëronte akoma një vend që tani thirret prej turëve Il Basan." Shyqyri Demiri. Histori e shkurtër e trevave të Elbasanit, f. 157. 


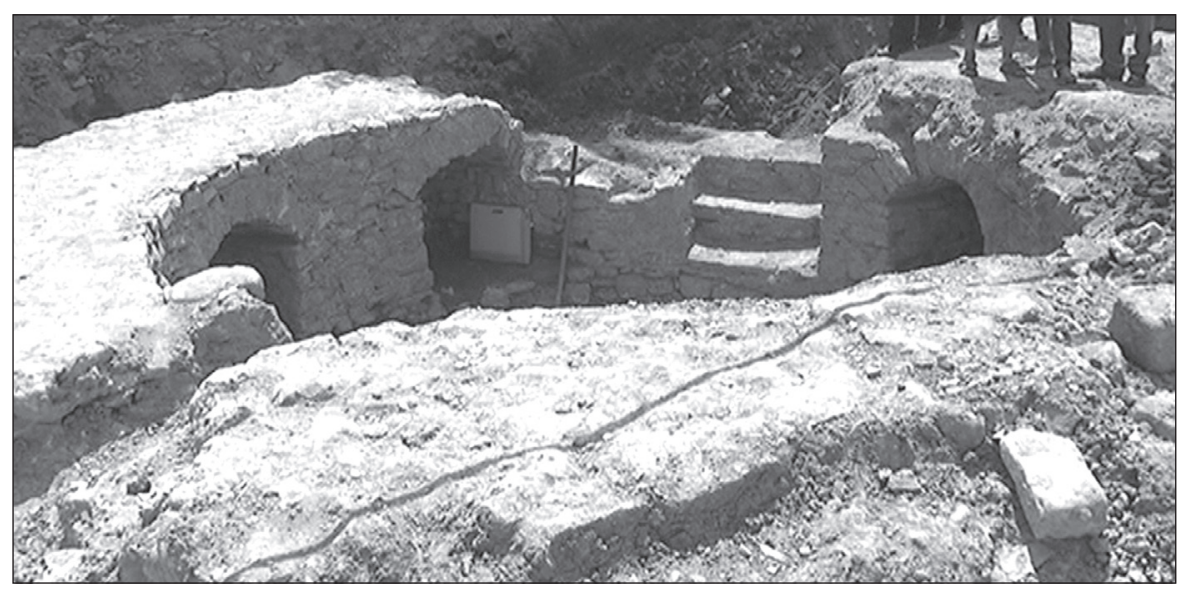

Pamja e pjesshme e objektit të zbuluar në rrugën "Thoma Kalefi".

për herë të parë në mbishkrimin e lënë prej Onufrit në kishën e shën Premtes në Valsh në vitin $1554 .{ }^{1}$

Pra, sipas këtyre të dhënave, "Jenixhe kalaja" është emri të cilin e përdorën kronikanët, por tashmë në gjuhën turke për kalanë e Elbasanit. Kështu, mendojmë se muri fortifikues zbuluar nuk ka të bëjë me "jenixhe kalanë", d.mth. me një kala të re, siç është thënë dhe as me "Jeniçer kalanë"2 që përmendet në disa shkrime.

Natyrshëm lind pyetja se kujt i përket dhe çfarë përfaqëson ky zbulim ?

Duke u bazuar në teknikën e ndërtimit të murit e sidomos në elementet fortifikuese të kullës së zbuluar siç janë frëngjitë për përdorimin e armëve të zjarrit, ky objekt duhet t'i përkasë periudhës së vonë osmane, fundit të shekullit të XVIII dhe fillimit të shekullit të XIX. Kjo veprimtari ndërtuese është e lidhur me krijimin e klasës feudale vendase brenda gjirit të klasës feudale osmane.

Feudalët vendas e shtrinë ndikimin e tyre në krahinat ku ishin vendosur dhe me anë të lidhjeve që krijuan kryesisht nëpërmjet martesave dhe krushqive, krijuan oligarkitë aristokratike feudale që u quajtën "Oxhaqe", të cilat ishin në rivalitet midis tyre. Në Elbasan, në shekullin e XVIII përmenden si familje të mëdha feudale Vërlacët, Taushanët dhe Biçakçijtë. ${ }^{3}$

1 Theofan Popa, Mbishkrime të kishave në Shqipëri, Tiranë 1998, f. 55.

2 Në disa shkrime pretendohet për ekzistencën në këtë vend të një "Jeniçer kalaje d.mth. të një kala të jeniçerëve". Mendojmë se në këtë rast gabimisht është zëvëndësuar emri "Jenixhe kala" me"Jeniçer kala".

3 Në fund të shekulli të XIX nuk do të na përmenden më Taushanët, siç duket "kanë rënë nga vakti", por do të përmenden Karaosmanët. 


\section{Albanon}

Revistë kulturore

Me krijimin e pashallëqeve të mëdha shqiptare (1771-1831), sanxhaku i Elbasanit gjatë kohës së ekzistencës së tyre, herë do të jetë nën qeverisjen e pashallëkut të Shkodrës (Bushatllijve), herë nën atë të Beratit (Ahmet Kurt Pashës), herë nën atë të Ali Pashë Tepelenës.

Kur në krye të pashallëkut të Shkodrës, do të vijë Ibrahim Pashë Bushatlliu (1797-1809), si qeveritar i sanxhakut të Elbasanit do të emërohet nipi i tij, Mehmet Pasha. Në sajë të politikës, qoftë të jashtme qoftë të brendshme që ndoqi I. P. Bushatlliu, për disa vjet u kalua në një periudhë relativisht të qetë dhe kjo i dha mundësi të mira vendit për zhvillim, sidomos veprimtarisë ndërtuese. Në vitin 1802 vdiq Mehmet Pasha dhe sanxhaku i Elbasanit kalon në duart e Ali Pashës. Në vitin 1804, sulltani ua kthen përsëri Bushatllijve dhe në Elbasan do të emërohet dhëndri i Bushatlliut, Ahmet Pashë Tirana. ${ }^{1}$

Duke njohur këta pashallarë që kanë qenë në krye të këtij sanxhaku të rëndësishëm, të jepet e drejta të mendosh se ky ndërtim, d.m.th. muri i zbuluar, të ketë shërbyer si mur rrethimi fortifikues për mbrojtjen e sarajeve të pashallarëve. ${ }^{2}$

Një e dhënë e cila si të thuash “ $i$ vë vulën” që këtu kemi të bëjmë me saraje pashallarësh, është ajo që na sjell prof. Shyqyri Demiri. Ai kur flet për xhaminë e Nazireshës, thotë se "pranë saj janë edhe disa gërmadha që mund të kenë qenë saraje feudale... Deri vonë, thotë profesori, toponimi "Te Sarajet”, i referohej vendit në perëndim të Namasgjasë."

Ky objekt i është shtuar pasurisë historike dhe arkeologjike të qytetit të Elbasanit. Ai është dëshmi e zhvillimit të qytetit në një periudhë të caktuar historike. Po kush ka qenë pashai i këtyre sarajeve?

Mendojmë se duhet ta kërkojmë midis këtyre emrave dhe familjeve feudale që tashmë i dimë.

1 Historia e popullit Shqiptar, Toena 2000, f. 650- 651.

2 Gjerak Karaiskaj, 5000 vjet fortifikime mbrojtëse. citon: "Në qytetet kryesore të pashallëqeve, ruhen gjurmë të rëndësishme të ndërtimeve mbrojtëse." f. 205.

3 Shyqyri Demiri, Histori e shkurtër e trevave të Elbasanit, f. 160. 